\title{
Metaphyseal Fracture Healing
}

Olof Sandberg
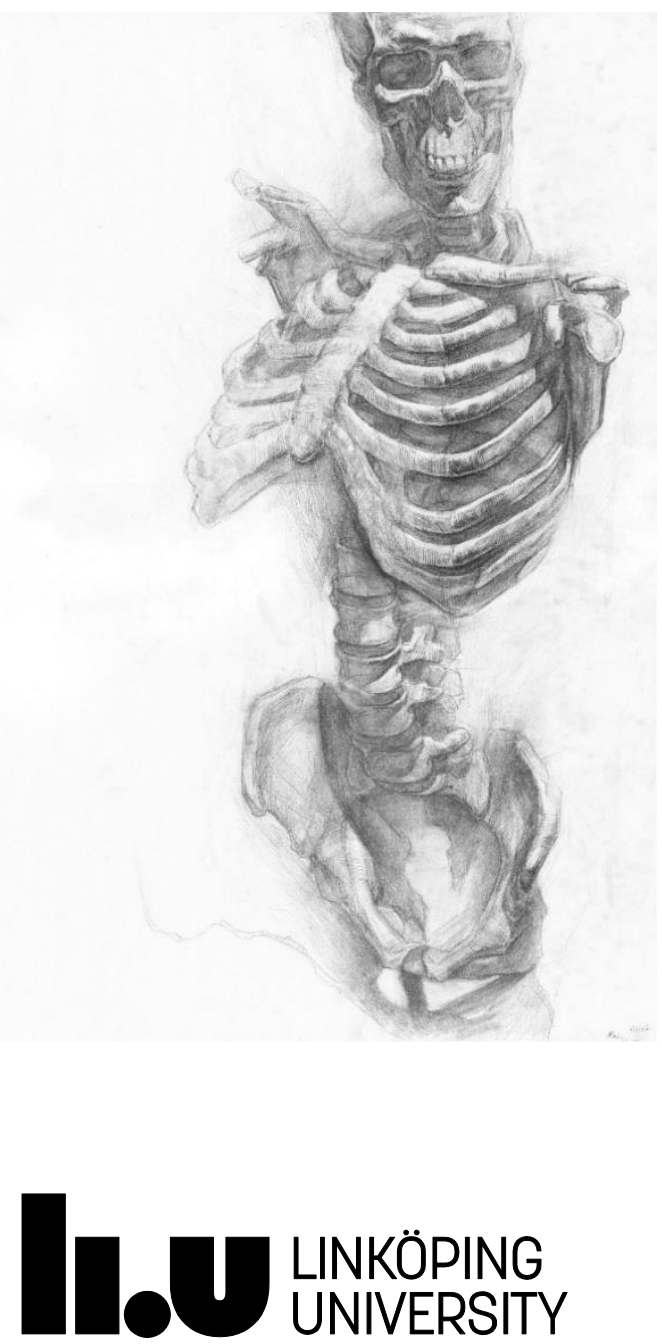

Division of Clinical Sciences

Department of Clinical and Experimental Medicine Medical Faculty

Linköping 2016 


\section{Supervisor Per Aspenberg}

Professor, Department of Clinical and Experimental Medicine

Linköping University

\section{Co-supervisor Ola Wahlström}

Professor Emeritus, Department of Clinical and Experimental Medicine Linköping University

\section{Faculty Opponent Aaron Schindeler}

Associate Professor, Pediatrics \& Child Health, Sydney Medical School

University of Sydney

Front illustration adapted with permission and copyright $(\mathbb{C}$ of the British Editorial Society of Bone and Joint Surgery Charnley J, Baker SL. Compression arthrodesis of the knee: a clinical and histological study. J Bone Joint Surg [Br] 1952;34-B:187-199. (Figure 11)

Illustration of a skeleton reprinted with permission from Paul Schwarz.

Drawings of mouse and syringe on back cover made by Freepik from www.flaticon.com Drawing of rat on back cover made by Vectorportal.com via www.flaticon.com Photo of external fixation on back cover from RISystem AG, Davos, Switzerland.

Published articles have been reprinted with permission of the respective copyright owners. Printed by LiU-Tryck, Linköping, Sweden, Mars 2016

ISBN: 978-91-7685-865-3

ISSN: 0345-0082

During the course of the research underlying this thesis, Olof Sandberg was enrolled in Forum Scientium, a multidisciplinary doctoral program at Linköping University, Sweden.

(C) Olof Sandberg, 2016 


\section{Abstract}

Most of what is known about fracture healing comes from studies of shaft fractures in long bones. In contrast, patients more often have fractures closer to the ends (metaphyses). Here most bone tissue has a spongy, cancellous structure different from the compact bone of the shaft. There is an increasing awareness that metaphyseal fractures heal differently. However, the more easily studied shaft healing has usually been considered as good enough representative for fracture healing in general.

My work shows that the biology of metaphyseal healing is more different from shaft healing than was previously known and that this has implications on the effect of various commonly prescribed drugs.

First we studied biopsies of healing cancellous bone collected from human donors. We found that the most abundant new bone formation occurred freely in the marrow rather than on the surface of old trabeculae, as described in most literature. There was little cartilage, indicating that the dominant bone formation process is mostly membranous in nature. This is a contrast to the ample cartilage formation commonly found in the well-characterized shaft fracture models.

Next we characterized a model that allows for mechanical quantification of regenerating cancellous bone. By contrasting this cancellous healing model with the standard shaft healing model we could demonstrate that the NSAID indomethacin, the glucocorticoid dexamethasone, and the bisphosphonate alendronate all had different effects on the mechanical quality of bone regeneration in shaft and metaphysis; while anti-inflammatory drugs strongly impaired shaft healing, metaphyseal healing was not similarly affected. Alendronate had a positive effect on both models, though the effect was strongest in the metaphyseal model. Taken together these differences shed some light as to the differences in healing biology.

The last step (within the boundaries of this thesis) was a characterization of how healing in cortical and cancellous bone differs in terms of immune cell involvement. We could find little difference between the two bone types day 3 . However, day 5 an increase in the number of granulocytes could be noted in the cancellous bone while the cortical bone had a higher number of lymphocytes.

To conclude, this work furthers our understanding of how metaphyseal healing differs from shaft healing. It has clinical implications as it motivates an increased attention to the site of fracture while contemplating treatment. I hope this thesis can be read as an argument for increased interest in metaphyseal fracture healing. 


\section{Populärvetenskaplig sammanfattning}

Benvävnad kan antingen vara kompakt eller porös och kallas då för kortikal respektive spongiös. Kortikal benvävnad utgör det hårda yttre skalet på alla skelettdelar, spongiös benvävnad finns bland annat inuti ryggkotorna och $\mathrm{i}$ ändarna på de långa rörbenen. Så gott som alla studier av frakturläkning görs på frakturer $i$ kortikalt ben. Man vet alltså mycket om hur kortikalt ben läker men betydligt mindre om hur spongiöst ben läker. Länge har man valt att för enkelhetens skull anta att det man vet om läkningen av kortikalt ben gäller även för läkning i spongiöst ben. Vi fann dock att läkningsbiologin i spongiöst ben är mer särpräglad än man tidigare trott. Frakturer i denna vävnadstyp är dessutom vanligare bland patienter. Därför anser vi att ökat fokus bör läggas på att förstå läkning i spongiöst ben. Man bör även tydligare än vad som nu sker uppmärksamma skillnaderna mellan läkning i kortikalt och spongiöst ben.

Vi fann att spongiöst ben läker utan brosk (kortikalt ben läker genom en process där det först bildas brosk som sedan gradvis ersätts av ben). Vi fann även att vid frakturer i spongiös benvävnad bildas nytt ben fritt i märgen, i ett förlopp snabbare än vid kortikala skador. En annan egenhet var att benbildningen bara bredde ut sig ett fåtal millimeter från det skadade området, mycket mindre än $i$ ett skaft där läkningsreaktionen kan täcka ett betydligt större område. Vi drar slutsatsen att samma signaler som avgränsar läkningen i spongiösa frakturer inte verkar vara verksamma i skaftfrakturer.

Eftersom det finns skillnader $i$ hur frakturer i kortikalt och spongiöst ben läker undersökte vi om de också påverkades olika av läkemedel. Vi testade den relativa effekten av tre preparat från vanligt förekommande läkemedelsfamiljer, där även varunamn som Voltaren, Ipren, Kortison, och Fosamax ingår. De preparat vi undersökte heter indomethacin, dexametason, och alendronat. Tidigare djurförsök har visat på effekter på läkningsprocessen (i skaft). Vi fann dock att den relativa effekten av indomethacin och dexametason var betydligt mindre i spongiöst ben än i kortikalt ben. Alendronat hade en relativt starkare effekt i spongiöst ben än i kortikalt ben. Avslutningsvis studerade vi immunförsvarets reaktion på fraktur $i$ spongiös och kortikal benvävnad för att på cellnivå försöka förstå mer av vad som sker under läkningen i respektive vävnad. Vi fann skillnader, men kan inte avgöra om dessa orsakade de skillnader vi såg i läkemedelsrespons. 


\section{The thesis is based on the following papers}

I. Distal radial fractures heal by direct woven bone formation P Aspenberg, O Sandberg Acta Orthopaedica 84 (3), 297-300, 2013

II. Experimental models for cancellous bone healing in the rat: Comparison of drill holes and implanted screws.

M Bernhardsson, O Sandberg, P Aspenberg Acta Orthopaedica 86 (6), 745-750, 2015

III. Different effects of alendronate in metaphyseal versus diaphyseal bone healing

OH Sandberg, ME Bernhardsson, P Aspenberg Submitted Manuscript

IV. Different effects of indomethacin on healing of shaft and metaphyseal fractures

O Sandberg, P Aspenberg Acta Orthopaedica 86 (2), 243-247, 2014

V. Glucocorticoids inhibit shaft fracture healing but not metaphyseal bone regeneration under stable mechanical conditions

OH Sandberg, P Aspenberg

Bone and Joint Research 4 (10), 170-175, 2015

VI. Macrophage depletion inhibits the healing of cancellous bone OH Sandberg, P Aspenberg Manuscript

VII. Leukocytes in Cortical and Cancellous Bone Healing: A comparison in mice.

L Tätting, O Sandberg, M Bernhardsson, J Ernerudh, P Aspenberg, Manuscript 


\section{Additional papers not included in the thesis}

- Osteoblast-derived WNT16 represses osteoclastogenesis and prevents cortical bone fragility fractures

Movérare-Skrtic S, Henning P, Liu X, Nagano K, Saito H, Börjesson AE, Sjögren K, Windahl SH, Farman H, Kindlund B, Engdahl C, Koskela A, Zhang FP, Eriksson EE, Zaman F, Hammarstedt A, Isaksson H, Bally M, Kassem A, Lindholm C, Sandberg O, Aspenberg P, Sävendahl L, Feng JQ, Tuckermann J, Tuukkanen J, Poutanen M, Baron R, Lerner UH, Gori F, Ohlsson C.

Nature medicine 20 (11), 1279-1288, 2014

- Bisphosphonate-induced osteonecrosis of the jaw in a rat model arises first after the bone has become exposed. No primary necrosis in unexposed bone J Abtahi, F Agholme, O Sandberg, P Aspenberg Journal of Oral Pathology \& Medicine 41 (6), 494-499, 2012

- Effect of local vs. systemic bisphosphonate delivery on dental implant fixation in a model of osteonecrosis of the jaw

J Abtahi, F Agholme, O Sandberg, P Aspenberg Journal of dental research 92 (3), 279-283, 2013

- Low-level mechanical stimulation is sufficient to improve tendon healing in rats T Andersson, P Eliasson, M Hammerman, O Sandberg, P Aspenberg Journal of applied physiology 113 (9), 1398-1402, 2012

- Histology of 8 atypical femoral fractures: Remodeling but no healing J Schilcher, O Sandberg, H Isaksson, P Aspenberg

Acta orthopaedica 85 (3), 280-286, 2014

- Etanercept does not impair healing in rat models of tendon or metaphyseal bone injury

O Sandberg, P Eliasson, T Andersson, F Agholme, P Aspenberg Acta orthopaedica 83 (3), 305-310, 2012

- Anti-RANKL treatment improves screw fixation in cancellous bone in rats M Bernhardsson, O Sandberg, P Aspenberg Injury 46 (6), 990-995, 2015

- Influence of a lower leg brace on traction force in healthy and ruptured Achilles tendons

OH Sandberg, I Dånmark, P Eliasson, P Aspenberg

Muscles, ligaments and tendons journal 5 (2), 63, 2015

- Low dose PTH improves metaphyseal bone healing more when muscles are paralyzed

O Sandberg, BR Macias, P Aspenberg

Bone 63, 15-19, 2014 


\section{Acknowledgements}

Per för din energiska och generösa stil

Ola för ditt vänliga bemötande

Fredrik för att du gick före och lärde mig handgreppen

Pernilla för din öppna dörr

Anna för dina råd och inspiration

Bibbi, Brandon, Franchiele, Jahan, Jörg, Magnus, Malin, Love, Parmis, Therese, och

Veronika för ovärderligt samarbete på labbet, kontoret, och puben

Annelie, Cynthia, Erik, Ivana, Sebastian, Susanna, och KEF för fikarumshäng etc

Per, Anna, Magnus, och Markus för era synpunkter på manuset

Forum, Domfil, Innebandy-gänget

Familj 


\section{Table of contents}

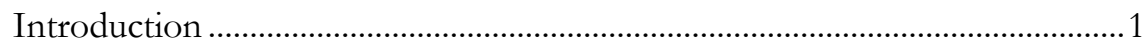

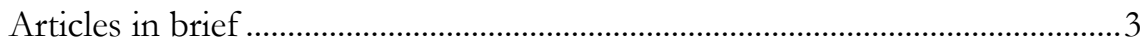

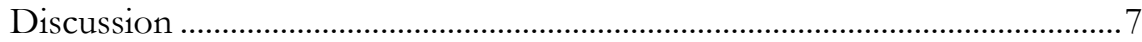

Healing in cancellous bone is fast and locally constrained ...........................

Endosteal cells are prone to direct membranous formation .......................... 8

Cancellous and cortical healing have different stem cell availability ...........9

Regeneration after cancellous bone injury leads to systemic effects .........10

Inflammation plays different roles in cancellous and cortical healing ......10

Cancellous bone healing is sensitive to pharmacological stimulation .......12

Murine models are useful as proof of concept ............................................12

Mechanical evaluation of cancellous healing requires special concerns....13

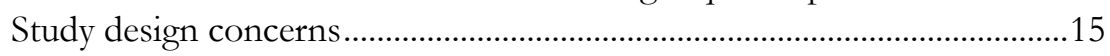

Summary of discussion points and open questions ...........................................17

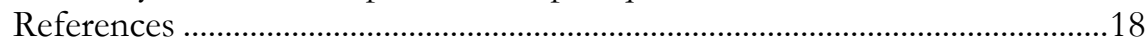




\section{Introduction}

Injury to cancellous bone is common. It may dominate in vertebral compression, distal radial fractures, tibial condyle fractures, and other injuries. However, injury to the cortical bone of the shaft is more easily studied. Therefore most of our understanding of fracture healing is skewed towards cortical healing.

The process of cortical healing is well characterized [1,2]. So too is the effect of various manipulations thereof. Briefly, the healing cascade starts with hematoma, followed by inflammation, formation of cartilage, which then is replaced by bone. Thus in shaft healing endochondral ossification dominates, at least in the center of unstable fractures. Simultaneously, periosteal membranous bone formation occurs further away from the fracture line, gradually closing in on it.

Compared to cortical bone healing cancellous bone healing is understudied. It is dominated by membranous bone formation and can be a fast process: a drill hole in cancellous bone in rodents can be filled with new bone tissue in less than a week. If a screw is inserted in the hole, its fixation is several fold improved in a similarly short time [3]. In contrast, endochondral healing of shaft fractures in similar species can take about three times longer to reach comparable mechanical and radiological healing.

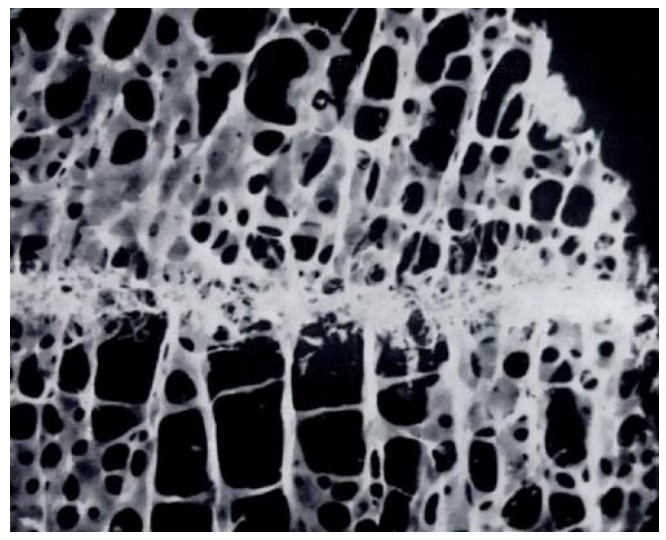

Figure 1. Photograph of a micro-dissected biopsy taken only 4 weeks after knee arthrodesis in a human, comprising the junction between the femur and tibia. Note the spatially limited new bone that welds the femur and tibia together. From Charnley and Baker [4] with permission.

Bone formation after injury in cancellous bone is typically strictly localized to the injured region and appears not to spread away from it (Fig 1). Therefore, the filling of a defect in cancellous bone wider than a few millimeters can be slow or incomplete. This is different from shaft fracture healing that can fill up considerable 
gaps. John Charnley showed already in the 1950s that human knee arthrodeses could heal in as little as 4 weeks if the cancellous resection surfaces fitted perfectly together, but not at all if there was a small gap. He comments that the cancellous bone formation response to trauma rarely extended more than $2 \mathrm{~mm}$ from the traumatized area (Fig 1) [4].

\section{The aim of this thesis}

We perceive a contradiction; while cancellous bone healing has a unique biology and fractures in areas of cancellous bone are the most frequent in the emergency ward, only a small portion of fracture healing research is spent studying cancellous healing.

Therefore the aim of this thesis is to further the knowledge of cancellous bone healing biology and how it distinguishes itself from its cortical counterpart. By contrasting the response of the two in a battery of different clinically relevant drugs, we wish to demonstrate the importance of keeping the differences between cancellous and cortical in mind. We also aim to further the understanding of the nature of that difference.

\section{In this thesis, I propose that}

- The biology of fracture healing in cortical and cancellous bone is markedly different

- The differences involve histological appearance, immune cell composition after trauma, and the response to several different drugs 


\section{Articles in brief}

\section{Article I, Distal radial fractures heal by direct woven bone formation}

Aim - Describe the histological appearance of early healing in human cancellous bone.

Method - A qualitative histological study of 12 biopsies 5 to 28 days after distal radius fracture.

Results - Osteoid was diffusely spread in the marrow after week 1, with little cartilage present.

Conclusion - Cancellous bone has a distinct healing biology.

\section{Article II, Experimental models for cancellous bone healing in the rat}

Aim - Characterize how and to what extent the pullout force of a screw inserted in the metaphysis reflects bone healing.

Method - Rats received bilateral drill holes in the metaphysis of the tibia. Some drill holes had a metal or plastic screw inserted. Evaluation was done day 1 to 28 with mechanical pull-out testing for the metal screws and microCT for the plastic screws and empty drill holes.

Results - Bone volume in the drill hole and around the plastic screws peaked day 7. The pullout-force increased sharply from day 1 to day 7 and remained stable into day 14 and 28. Removing cancellous bone reduced the pull-out force by half day 7 and $20 \%$ day 28 .

Conclusion - Up to day 7 the increase in pullout-force primarily reflects the increase in bone regenerate volume.

\section{Article III, Different effects of alendronate in metaphyseal versus diaphyseal bone healing}

Aim - To determine if bisphosphonates affect metaphyseal and diaphyseal healing differently.

Method - Mice received either a midshaft osteotomy, with relatively unstable intramedullar nailing, or bilateral holes drilled in the metaphysis of the tibia with a screw inserted in the right hole. They were randomized to receive $200 \mathrm{ug} / \mathrm{kg} / \mathrm{day}$ of alendronate or saline. Healing was evaluated day 14 and 21. Pullout force of the screw and radio density of the empty drill hole was measured, as well as three point maximum force and callus size and density for the midshaft. A material testing machine and a microCT were used.

Results - Alendronate increased the healing in both models. The effect appeared stronger in the metaphyseal model. 
Conclusion - Differences in healing biology give differences in response to bisphosphonates.

\section{Article IV, Different effects of indomethacin on healing of shaft and metaphyseal fractures}

Aim - To determine if NSAIDs affect metaphyseal and diaphyseal healing differently.

Method - The set up and evaluation from article III was used. The treatment group received subcutaneous injections of indomethacin $1 \mathrm{mg} / \mathrm{kg}$ twice per day. The end points were changed to 7 days for the metaphyseal model and 19 days for the midshaft.

Results - In the midshaft model, maximum force and callus size each decreased by about $35 \%$. In the metaphyseal model, healing was less affected with no effect on pull-out force and a $12 \%$ drop in BV of the drill hole.

Conclusion - Differences in healing biology lead to differences in the response to NSAIDs.

\section{Article V, Glucocorticoids inhibit shaft fracture healing but not metaphyseal} bone regeneration under stable mechanical conditions

Aim - To determine if glucocorticoids affect shaft and metaphyseal healing differentially; and if so, if stability is a factor.

Method - Set-up and evaluation protocol was duplicated from article IV, with addition of a group with a stable externally fixated midshaft model. After surgery, animals were randomized to control injections or $2 \mathrm{mg} / \mathrm{kg}$ injections of dexamethasone three times per week.

Results - Maximum force was lowered by half in the shaft, regardless of stability. In the metaphysis it was increased by $18 \%$.

Conclusion - Differences in healing biology lead to differences in the response to corticosteroids, regardless of stability.

\section{Article VI, Macrophage depletion inhibits cancellous bone healing}

Aim - To determine if macrophage depletion inhibits cancellous healing.

Method - Mice received $0.2 \mathrm{ml}$ clodronate liposome injections IP inducing macrophage depletion either day -2 to 1 or day -2 to 5 . The metaphyseal model setup and evaluation from article IV was duplicated.

Results - Clodronate injections lowered the pull-out force by half and the BV of the drill hole by $70 \%$. There was no additional effect from prolonging the inhibition to day 5 . 
Conclusion - Presence of macrophages shortly after trauma is needed for cancellous healing.

\section{Article VII, Leukocytes in cortical and cancellous bone healing}

Aim - To describe the immune cell reaction to fracture and possible differences between shaft and metaphyseal injury.

Method - Mice had a stable bone injury to the metaphysis or shaft. Cells from the marrow of the injured regions day 3 and 5 were analyzed by flow cytometry using 15 different surface markers.

Results - The profile day 3 was similar in metaphysis and shaft. In the metaphysis, granulocyte numbers increased from day 3 to day 5 , comprising half of all leukocytes. In the shaft, there was instead an increase in lymphocytes numbers.

Conclusion - The immune system response to injury differs between shaft and metaphysis. 


\section{Discussion}

\section{Healing in cancellous bone is fast and locally constrained}

We found that in murines 7 days of healing is sufficient for a metaphyseal drill hole to be filled with mineralized woven bone clearly visible by histology and microCT (Fig 2) [3]. In human distal radius fractures, we found osteoid as early as the second week after fracture (Fig 3) [5]. Similarly fast ossification in distal radial fractures has been reported by others $[6,7]$ and studies in human vertebrae and animal models show similar phenomena $[8,9]$.

The cancellous healing process after trauma starts with a hematoma followed by inflammation. In mice, the inflammatory phase seems to peak between day 0 and day 3 after a shaft fracture, as measured by inflammatory cytokines TNF- $\alpha$ and IL1B levels [10]. Inflammation is followed by mesenchymal cell condensations forming osteoid, which becomes woven bone (Fig 4). This is then remodeled into lamellar bone $[4,9,11]$.

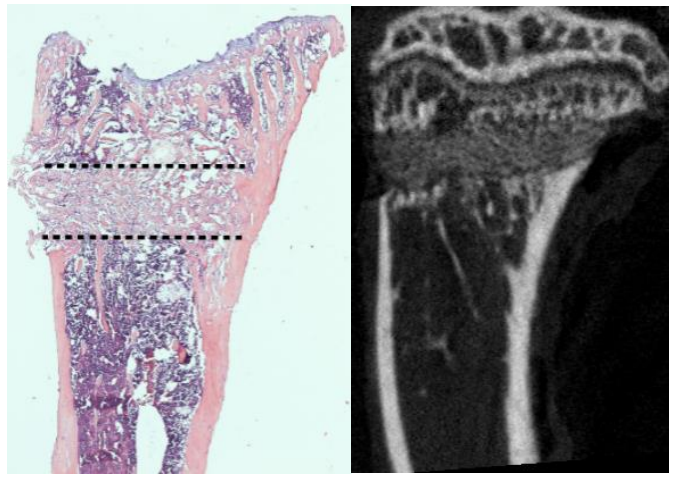

Figure 2. A drill hole in the proximal tibia of a mouse after 7 days. Not the same specimen.

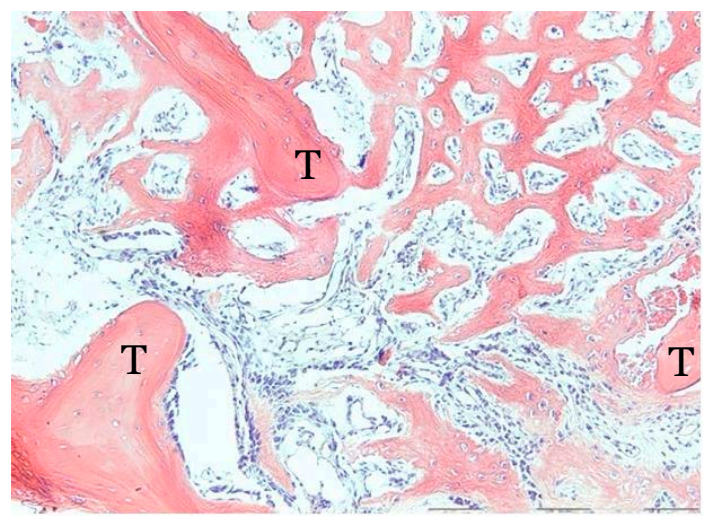

Figure 3. Human distal radius 16 days after fracture. T indicates old trabeculae. 

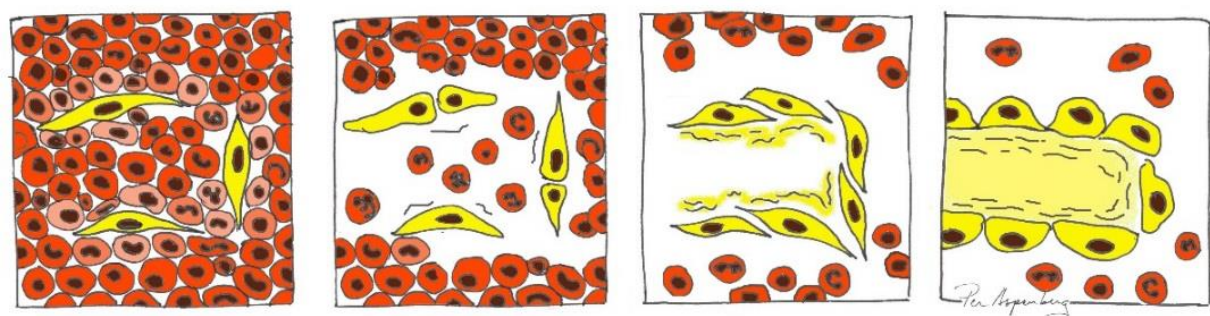

Figure 4. A schematic of bone formation in the cancellous compartment of the metaphysis. Yellow cells represent MSCs turning into bone forming osteoblasts.

In our experiments osteoid formed simultaneously throughout the traumatized marrow volume rather than mostly on the surfaces of old trabeculae, which has previously been thought to dominate. This formation throughout the traumatized volume can explain the fast response of cancellous fracture healing. Apparently, stromal cells residing in the marrow become activated to form bone diffusely spread throughout the traumatized marrow. This appears very different from diaphyseal fracture healing as we know it from the textbooks. In contrast a recent paper reported little cell proliferation in a metaphyseal healing model in mouse and drew the conclusion that stem cell proliferation is likely not directly involved in the formation of new bone tissue [12]. However as the only time point analyzed was day 7 after fracture most new bone formation had most likely already occurred.

\section{Endosteal cells are prone to direct membranous formation}

We have seen that mechanically stable cancellous fractures heal mainly without cartilage or external callus, as has also been reported elsewhere [13]. Cells in the marrow seem predisposed to respond to trauma with membranous bone formation while cells in the periosteum are more inclined to follow the endochondral route [14-16]. This was nicely shown in a mouse experiment where cortical autografts were inserted in a fracture. When the periosteal side of the graft pointed outwards from the fracture it developed endochondral bone formation. When flipped so that the periosteal side faced inwards, it still produced bone through the endochondral pathway, now in the marrow. Conversely, the endosteal side mainly produced woven bone, also regardless of position [15].

There are many studies of shaft healing which differentiates between endochondral and membranous bone formation. In shaft fracture membranous bone formation occurs distal and proximal of the fracture, in the periosteum. For reason described above as well as below we do not believe periosteal membranous bone formation following shaft fracture is identical to the intra-marrow ossification seen in a 
metaphyseal fracture. Therefor this discussion focuses on the intra-marrow ossification and omits most studies of periosteal membranous bone formation.

Cartilage was rarely seen in our human biopsies, nor in our murine cancellous healing samples. Cartilage formation might be related to low oxygen tension. Instability, or rather micromotion, will induce cartilage formation in both cancellous and cortical healing [17-24]. However, cancellous fractures are generally stable in the sense that repeated cyclic deformation of a considerable magnitude is unlikely to occur. Another property that is rather specific for metaphyseal fractures is the relative absence of an external callus, to some extent this is due to limited motion. As a side note, we therefore interpret the high stability of our screw model as relevant for metaphyseal fractures.

A slight cyclic deformation has been showed to be beneficial for optimal bone formation in traumatized cancellous bone both in humans and animals $[17,25,26]$.

\section{Cancellous and cortical healing have different stem cell availability}

The shaft fracture healing literature is inconclusive as regards the relative contribution of cells from marrow, endosteum, periosteum, surrounding tissues, and circulation. This is the subject of an ongoing debate that has lasted 200 years [2729]. Today it seems that while the periosteal contribution to healing is of major importance in shaft healing, other sources can compensate if the periosteal source is compromised [30]. Roughly $10 \%$ of the regenerate in a diaphyseal mouse fracture has been estimated to originate from cells derived from the circulation [31].

We believe that one of the most important differences between shaft and metaphyseal healing is the relative availability of stem cells. Bone formation in the metaphyseal marrow has been suggested to likely be less dependent on periosteum, circulation, or other tissues, as compared to bone formation in shaft [32]. This is partly because the metaphyseal marrow is known to have higher numbers of mesenchymal stem cells (MSCs), also more committed towards an osteogenic fate [33]. In a metaphyseal drill hole, a cancellous autograft produced more bone formation than a bone marrow concentrate enriched to a 3.5 times higher MSC content. Other differences aside, this could imply that MSC numbers is usually not a rate limiting factor in cancellous bone healing [34].

The literature has little to say about the role of MSC recruitment in cancellous healing. In a pilot, we administered a stem cell recruitment inhibitor AMD3100 to both shaft and metaphyseal healing mice and although there was a trend towards a more negative effect on healing in the shaft this was not significant [unpublished data]. However it is possible that this was an optimization issue and that further 
studies could show that metaphyseal healing is significantly less dependent on functional off-site MSC recruitment.

\section{Regeneration after cancellous bone injury leads to systemic effects}

When bone marrow regenerates after trauma this leads to a systemic increase in bone formation rate: up to a quadrupling in other cancellous bone sites in the body [35]. Interestingly, the systemic response is lost if the traumatized volume is filled up with a replacement material, demonstrating that something in the regenerating tissue, and not in the trauma itself, lies behind the systemic effect [36]. Experiments using serum from fracture patients have shown to upregulate cell proliferation in Vitro [37]. We have seen with flow cytometry in cancellous fracture mice that a fracture in one bone within one day induces a systemic immune response in both contralateral as well as other bone locations [unpublished data]. A conclusion we draw is that it is possible that the systemic upregulation of bone formation is partly mediated via interplay with the immune system.

\section{Inflammation plays different roles in cancellous and cortical healing}

The event of a fracture, as well as the healing thereof, will cause reactions in the immune cell population. Traumatic injury will induce responses affecting up to $80 \%$ of the transcriptome in leucocytes [38] and differences in the expression of some immune cell markers has been shown to correlate with recovery outcome after hip replacement surgery [39].

One of the key findings of this thesis is that administration of anti-inflammatory drugs seems to have less of an effect in cancellous fractures than in shaft fractures $[3,40,41]$. There is evidence of a direct link between dysfunctional inflammatory signaling in chondrocytes and unsatisfactory endochondral bone formation [42] (important for shaft healing). In contrast to this, membranous healing in a metaphyseal drill hole model was unaffected by the disruption of intracellular osteoblast glucocorticoid signaling [43].

We suggest that the apparent difference in the effect of inflammation between cancellous and cortical healing might be linked to the differences in MSC availability between the shaft and the metaphysis. Inflammation is important for cell recruitment in fracture healing [44] and as mentioned above recruitment from distant sources might be more crucial in cortical fractures but less so in the cancellous fractures of the metaphysis.

In contrast to our findings, another group found delayed membranous bone formation following marrow ablation in mice with permanently reduced proinflammatory cytokine $\mathrm{TNF}-\alpha$ receptor expression. Mice receiving a shaft fracture also had reduced healing in association with the reduced receptor expression. 
However, in the shaft fracture model, mRNA levels of osteocalcin and collagen 1a1 were increased from day 10 while in the membranous marrow ablation model this was not so. The paper concludes that cortical and cancellous bone have different healing biology [14] something our results are in support of.

NSAIDs effect is thought to be mediated via blocking the COX-2 pathway. WE found no effect of NSAID treatment on membranous bone formation in a cancellous drill hole. In contrast membranous bone formation was reduced by $80 \%$ in a mouse model where COX-2 was knocked out. This model used titanium particles surgically implanted onto calvaria [45] and the difference to our findings suggests that membranous bone formation in periosteum and intra-marrow space might not be directly comparable.

Turning to our flow cytometry data, our direct comparison of leucocyte numbers day 3 and 5 after trauma in shaft and metaphyseal healing revealed a "stronger" inflammatory reaction in the metaphysis. If this stronger inflammation in the metaphysis is more robust, it might be less impaired by NSAIDs or corticosteroids. This could be one possible explanation to the weaker effect of anti-inflammatory drugs in cancellous healing. However, the drug doses we used were high, and other explanations (see below) appear more likely.

Although NSAID by their very name are known as anti-inflammatory, experiments in our group on tendon healing show little effect on inflammatory cells [unpublished data]. It is possible that the effects of NSAIDs and glucocorticoids are exerted through other, perhaps mesenchymal cell-derived, channels.

The role of macrophages in fracture healing is relatively well studied though results are somewhat contradictory. They are key players in both the onset and resolution of inflammation [46] and are in the broadest of definitions divided into the inflammatory M1 subcategory and the anabolic M2 subcategory. In the shaft macrophages seem important for collagen deposition and for the conversion of cartilage into bone [47]. Their depletion leads to impaired callus formation [48] and impaired shaft fracture healing. In contrast, the role of macrophages in cancellous bone formation is less clear although the literature has shown close connections between macrophages and osteoblasts in healing [46, 49]. "Osteomacs" is a special term for these macrophages that are believed to closely interact with osteoblasts. Interestingly, macrophage depletion can lead both to increased membranous bone formation, in the periosteum [47], and decreased membranous bone formation, in the medullary space [49]. The anabolic effect of macrophages has been partly linked to Oncostatin M, a cytokine related to IL-6. Mice lacking the receptor for Oncostatin $\mathrm{M}$ will have a $50 \%$ reduction in new formed bone volume in metaphyseal drill holes after 7 days of healing [50]. 
Our results showed a remarkably strong negative effect on cancellous healing when phagocytosing macrophages were depleted day -2 to 1 . At this time point new osteoblasts are probably not yet formed. Our results suggest that whatever the crucial task of the macrophages could be, it needs to happen at the day of fracture as prolonged treatment had no additional effect. Further experiments are required to clarify this. A time sensitive effect was reported also in a shaft model where reduced macrophage numbers before the time of fracture had a stronger effect than if the reduction occurred 3 days after [51]. Similarly in a water salamander model where a foot was resected; regrowth of the limb was blocked permanently if clodronate liposomes were delivered before the surgery but not if the liposomes were injected at day 10 to 13 . After 150 days, the resected foot still had not grown back in the animals that were given clodronate before the resection. Most strikingly, a resection of the stump 150 days after the first resection, and this time without clodronate liposomes, did result in a foot growing back out [52].

\section{Cancellous bone healing is sensitive to pharmacological stimulation}

We found a stronger response to the net anabolic effect of bisphosphonates in the metaphysis compared to in the shaft. In our metaphyseal models, the robust bone formation seen day 5 to 7 started to be resorbed already by day 10 to 14 . As a consequence, anti-resorptive drugs such as bisphosphonates and denosumab should be expected to have a greater effect in these settings compared to the setting of shaft healing.

Some studies report that trabeculae in the vicinity of a cancellous fracture will increase in thickness [53-55]. One article reports a fivefold increase in bone formation rate, but also in resorption, giving no net increase in bone [56]. It seems the coupling between resorption and formation is still functional in the vicinity of the fracture but in the fracture itself a single look in the microscope shows how bone formation dominates completely, indicating that it is uncoupled from resorption.

We could see an increase in cancellous healing both with dexamethasone, alendronate, and PTH. Many substances that influence bone will have an effect on cancellous bone healing, including PTH, bisphosphonates, and antisclerostin antibodies. This demonstrates that although the cancellous healing response is robust it is still sensitive to manipulation by both anti-resorptive and anabolic drugs [3, 40, 57-63].

\section{Murine models are useful as proof of concept}

We use the mouse and the rat as proof-of-concept models. There are large differences between murines and humans. Regarding drug dosing these differences are unlikely to influence basic mechanisms since rather than to try to maximize clinical relevance we choose our drug regimens as to maximize the effect we are 
interested in studying. Generelly, murines can be seen as a first, fast, and cheap screening model with less ethical concerns connected to its use compared to many larger animals.

The rat and the mouse are the most popular model animals for fracture healing research, for good reasons [64]. In studies where gene modification is involved, the mouse is unparalleled in terms of ease of use and availability.

As the skeleton of a species is adapted to the needs of that species, there will invariably be important interspecies differences [65]. There can be a large variation in bone characteristics and fracture healing ability between different strains within a species $[66,67]$ for example up to ten-fold differences in leucocyte numbers in the peripheral circulation of different mouse strains [68]. Membranous bone formation volume 21 days after marrow ablation can differ four-fold when comparing different strains within the mouse species [69].

There are several species whose skeleton more closely resembles the human than the murine skeleton does. For murines one often mentioned difference except sheer size is, for mice, the lack of the Haversian system. For these reasons and others the FDA requires that drug evaluation should be performed in at least one larger animal aside from a rodent before human trials can be considered.

Mice and rats may load fractured bones as normally as possible, in a way no ordinary human fracture patients would. This is to be expected as a limping mouse lives a dangerous life: if spotted its disability will make it a favored target for predators. This means that a rodent model for fracture healing will most likely see a much higher loading under the early healing phase than we would see in a human patient.

Another noteworthy aspect of mice as models for healing is that since male mice fight for social supremacy, placing male mice one and one instead of 4 and 4 will serve as an unloading model, something not found for female mice (who do not fight) [70]. Indeed, looking at the data in our experiments we could see that mice that for some reason had been housed 1 and 1 had slower healing [data not shown].

\section{Mechanical evaluation of cancellous healing requires special concerns}

One main caveat in this thesis is the use of the fixation of a screw inserted into the cancellous bone of the metaphysis as a proxy for cancellous bone regeneration.

Cancellous bone functions to a large extent by resisting compression. However, tests of compressive strength of an osteotomy might be difficult to interpret, because fragments that have not united may still cause compression resistance after some impaction has occurred. Therefore, most models instead use osteotomies combined with different forms of bending tests. We have evaluated the alternative to insert 
screws in holes drilled into cancellous bone of the metaphysis. After a given period of healing the pull-out resistance can be measured. The pull-out force increases dramatically over the first weeks and correlates with the amount of new bone formed around the screw [71]. Estimations from finite element analysis in combination with screw pullout testing on human cadavers suggest that a change in screw positioning as small as $0.5 \mathrm{~mm}$ could change the pull-out force by up to $28 \%$ [72], indicating that pull-out force is sensitive to local variation in trabecular geometry.

The strength of a healing bone will determine when a patient can resume weightbearing without pain. Therefore we believe that studies into modulation of bone regeneration should have maximum force, or something to that effect, as the main outcome variable.

It is difficult to adequately evaluate cancellous healing mechanically and various imaging techniques present an easier option. However, it is difficult to assess the mechanical competence of bone (which is our main interest) from its radiological appearance [73]. The literature contains a number of models of cancellous bone healing that allow for mechanical evaluation, each with its pros and cons (Table I). While the screw model primarily tests the quality of the cancellous bone of the marrow, the 3-point bending technique employed by most other models by virtue of their design put an emphasis on the cortex (Fig 5).

Table I. Published models for mechanical evaluation in cancellous bone healing

\begin{tabular}{|c|c|c|c|c|c|}
\hline Model & Authors & Animal & $\begin{array}{l}\text { Evaluation } \\
\text { method }\end{array}$ & Pros & Cons \\
\hline $\begin{array}{l}\text { Osteotomy } \\
\text { Plate fixation }\end{array}$ & Histing [74] & Mouse & Torsion & $\begin{array}{l}\text { No external callus, no } \\
\text { cartilage }\end{array}$ & $\begin{array}{l}\text { Few trabeculae, } \\
\text { large variance }\end{array}$ \\
\hline $\begin{array}{l}\text { Osteotomy } \\
\text { Intramedullar pin }\end{array}$ & Tu [42] & Mouse & $\begin{array}{l}3 \text { point } \\
\text { bending }\end{array}$ & Simple & $\begin{array}{l}\text { Few trabeculae, } \\
\text { external callus, } \\
\text { cartilage, large } \\
\text { variance }\end{array}$ \\
\hline $\begin{array}{l}\text { Osteotomy } \\
\text { Plate fixation }\end{array}$ & Stuermer [75] & Rat & $\begin{array}{l}3 \text { point } \\
\text { bending }\end{array}$ & $\begin{array}{l}\text { Trabecular rich area, } \\
\text { small variance }\end{array}$ & External callus \\
\hline Drill defect & Uusitalo [76] & Mouse & $\begin{array}{l}3 \text { point } \\
\text { bending }\end{array}$ & $\begin{array}{l}\text { Trabecular rich area, } \\
\text { small variance, no } \\
\text { external callus, simple }\end{array}$ & Cartilage, unloaded \\
\hline $\begin{array}{l}\text { Osteotomy } \\
\text { Plate fixation }\end{array}$ & Alt [77] & Rat & $\begin{array}{l}3 \text { point } \\
\text { bending }\end{array}$ & Trabecular rich area & $\begin{array}{l}\text { External callus, } \\
\text { large variance }\end{array}$ \\
\hline $\begin{array}{l}\text { Partial osteotomy } \\
\text { External fixation }\end{array}$ & Tsiridis [59] & Rabbit & $\begin{array}{l}\text { Torsion } \\
\text { followed by } \\
\text { compression }\end{array}$ & $\begin{array}{l}\text { Small variance, both } \\
\text { torsion and } \\
\text { compression }\end{array}$ & $\begin{array}{l}\text { Large animal, few } \\
\text { trabeculae, external } \\
\text { callus }\end{array}$ \\
\hline $\begin{array}{l}\text { Drill defect } \\
\text { Screw insertion }\end{array}$ & $\begin{array}{l}\text { Skoglund [63] } \\
\text { Sandberg [3] }\end{array}$ & $\begin{array}{l}\text { Rat, } \\
\text { mouse }\end{array}$ & Pull-out test & $\begin{array}{l}\text { Simple, no external } \\
\text { callus, no cartilage, } \\
\text { trabecular rich area, } \\
\text { small variance }\end{array}$ & $\begin{array}{l}\text { Implant to bone } \\
\text { interaction, } \\
\text { unloaded }\end{array}$ \\
\hline
\end{tabular}

To call any metaphyseal healing model a cancellous healing model is a simplification as there is always a cortical shell that is also damaged by the surgery. In our characterization of the screw model, we could see that at week 1 about half of the resistance to pull-out came directly from the cancellous bone [71]. As cancellous 
fractures are usually accompanied by a fracture of the cortical shell in patients, we do not necessarily see any weakness in the fact that this is reflected also in our model.

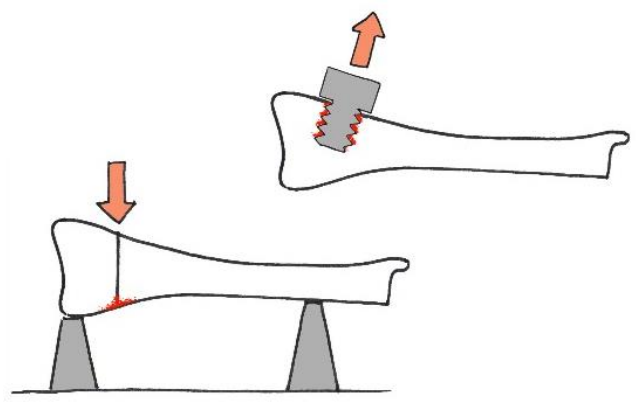

Figure 5. The principal mechanical testing methods for cancellous healing used in table I. The red color indicates the area of bone contributing most to the maximum force.

Fracture fixation is a major engineering challenge in the creation of metaphyseal healing models. In rodents, the cancellous part of the metaphysis does not extend far from the joint. This leaves little space for fixation devices. Moreover, the metaphysis is vaguely defined and several experimental models of metaphyseal healing use osteotomies at a level where there is little cancellous bone (see table I). In addition, rodents grow fast and a fracture induced in a cancellous region might after 3-4 weeks find itself in an empty medullary space. All of these factors combined contribute to the difficulty of producing a properly fixated metaphyseal fracture in rodents.

We believe that a relevant metaphyseal bone healing model should be situated where the marrow cavity contains cancellous bone. At the same time, it should be stable enough so that little cartilage and external callus forms. This combined with a sufficiently low variation of a relevant mechanical outcome variable. We believe our model is reasonable, avoiding many of the pitfalls of others, such as external callus, cartilage, and large variance.

\section{Study design concerns}

The aim of our work was to further our knowledge on cancellous healing, but also to contrast it to its cortical counterpart. A direct comparison of metaphyseal and shaft healing will by necessity be a comparison of pears and apples. Ironically, this might to some readers render it a fruitless comparison. The differences arise in part from the sterical differences between shaft and metaphysis, as well as from biological differences. This is further complicated by our desire to use the endpoint of mechanical strength. In one way the very reasons we are interested in making the comparison are the same reasons that make it a difficult comparison to make. 
It might seem a good idea to use the same time point for all models within an experiment (something we did in our bisphosphonate study). However, this might not always give the most meaningful results. The cancellous bone in our models can be said to heal in 5-7 days, the shaft in 17-21 days. Hence for optimal sensitivity to the effects of drugs that delay or speed up healing, the end point should be close to the time point were healing occurs in controls.

Including several time points is one way to increase the robustness of a study. However several time points means more data, this requires more complex statistics which makes it more difficult for readers to digest. It can increase the risk for false positives if a primary hypothesis is not stated beforehand. To reduce this risk our studies usually have effect on maximum force at one specific time point as the main hypothesis. All other variables are treated as secondary.

By necessity we need to use different ways to induce a fracture in the shaft and metaphysis. This is because currently it seems difficult to create a stable osteotomy in the metaphysis of mice. Conversely, a screw inserted into the cortical shell can give little interesting information of the healing process, as it will mostly reflect the strength of the pre-existing cortex. Intuitively, this difference in model types diminishes the value of the comparison we do. At the same time both models measure mechanical quality of a bone regenerate. As such we believe they are comparable in the aspects that matter most. 


\section{Summary of discussion points and open questions}

Most of our knowledge of fracture healing is based on studies of cortical midshaft fractures. The healing biology of these are known to differ from the more clinically relevant metaphyseal fractures, the latter occurring mostly in cancellous bone.

We found that a cancellous fracture responds with bone formation diffusely spread out in the marrow. This is likely one crucial factor in the fast response to metaphyseal trauma and indicates local MSCs (which are known to be plenty) as important sources for this regenerate. We found an absence of anti-inflammatory drug effects in cancellous bone. The absence of an effect can be explained if inflammation is important for MSC recruitment, since the well-stocked local reservoir of MSCs in cancellous bone makes MSC recruitment less important there, in comparison to shaft fractures. This remains a hypothesis which possibly could be studied directly via radiation induced destruction of marrow cells followed by injection of GFPmarked marrow cells, or possibly parasymbiosis to visualize the role of circulation derived stem cells.

We plan to use flow cytometry to further analyze the effect of NSAIDs and glucocorticoids in shaft and metaphysis healing. This might help explain why we found no inhibitory effect of dexamethasone and indomethacin in metaphyseal healing while shaft healing was inhibited. The apparent importance of macrophages already the first two days after trauma points to some crucial role of these cells. After those first days are over, it might be that the window of opportunity is closed and the healing permanently retarded. We now try to reach a deeper understanding of the mechanisms in further experiments.

The bone formation after cancellous trauma is very local, closely following the border of the induced trauma. It is therefore interesting that we observed in recent studies outside this thesis that in terms of cell numbers the immune response to trauma is mostly systemic. This opens up for the question as to what factors exerts this seemingly very precise limitation of the regeneration activity. Immunohistochemical studies which might answer this are on the way.

One factor often highlighted in fracture healing, but not in this thesis, is angiogenesis. This is likely different in a shaft (where inhibited angiogenesis is known to impair healing $[78,79])$ and a metaphyseal fracture.

Another example of an uncharted venue is age; the mice used in this thesis were all juvenile. With aging, local stem cell numbers decrease and the immune system becomes more pro-inflammatory, it could therefore be interesting to measure also the impact of age on the cancellous healing response. 


\section{References}

[1] Marsell R, Einhorn TA. The biology of fracture healing. Injury 2011;42: 551-5.

[2] Einhorn TA. The cell and molecular biology of fracture healing. Clin Orthop Relat Res 1998: S7-21.

[3] Sandberg O, Aspenberg P. Different effects of indomethacin on healing of shaft and metaphyseal fractures. Acta Orthop 2015;86: 243-7.

[4] Charnley J, Baker SL. Compression arthrodesis of the knee; a clinical and histological study. J Bone Joint Surg Br 1952;34-B: 187-99.

[5] Aspenberg $P$, Sandberg O. Distal radial fractures heal by direct woven bone formation. Acta Orthop 2013;84: 297-300.

[6] Sevitt S. The healing of fractures of the lower end of the radius. A histological and angiographic study. J Bone Joint Surg Br 1971;53: 519-31.

[7] de Jong JJ, Willems PC, Arts JJ, Bours SG, Brink PR, van Geel TA, Poeze M, Geusens PP, van Rietbergen $B$, van den Bergh JP. Assessment of the healing process in distal radius fractures by high resolution peripheral quantitative computed tomography. Bone 2014;64: 65-74.

[8] Diamond TH, Clark WA, Kumar SV. Histomorphometric analysis of fracture healing cascade in acute osteoporotic vertebral body fractures. Bone 2007;40: 775-80.

[9] Chen WT, Han da C, Zhang PX, Han N, Kou YH, Yin XF, Jiang BG. A special healing pattern in stable metaphyseal fractures. Acta Orthop 2015;86: 238-42.

[10] Kon T, Cho TJ, Aizawa T, Yamazaki M, Nooh N, Graves D, Gerstenfeld LC, Einhorn TA. Expression of osteoprotegerin, receptor activator of NF-kappaB ligand (osteoprotegerin ligand) and related proinflammatory cytokines during fracture healing. J Bone Miner Res 2001;16: 1004-14.

[11] Han D, Han N, Xue F, Zhang P. A novel specialized staging system for cancellous fracture healing, distinct from traditional healing pattern of diaphysis corticalfracture? Int J Clin Exp Med 2015;8: 1301-4.

[12] Han D, Han N, Chen $Y$, Zhang $P$, Jiang B. Healing of cancellous fracture in a novel mouse model. Am J Transl Res 2015;7: 2279-90.

[13] Han N, Zhang PX, Wang WB, Han DC, Chen JH, Zhan HB, Jiang BG. A new experimental model to study healing process of metaphyseal fracture. Chin Med J (Engl) 2012;125: 676-9.

[14] Gerstenfeld LC, Cho TJ, Kon T, Aizawa T, Cruceta J, Graves BD, Einhorn TA. Impaired intramembranous bone formation during bone repair in the absence of tumor necrosis factor-alpha signaling. Cells Tissues Organs 2001;169: 285-94.

[15] Colnot $C$. Skeletal cell fate decisions within periosteum and bone marrow during bone regeneration. J Bone Miner Res 2009;24: 274-82.

[16] Rabie AB, Dan Z, Samman N. Ultrastructural identification of cells involved in the healing of intramembranous and endochondral bones. Int J Oral Maxillofac Surg 1996;25: 383-8.

[17] Claes L, Reusch M, Gockelmann M, Ohnmacht M, Wehner T, Amling M, Beil FT, Ignatius A. Metaphyseal fracture healing follows similar biomechanical rules as diaphyseal healing. J Orthop Res 2011;29: 425-32.

[18] Jarry L, Uhthoff HK. Differences in healing of metaphyseal and diaphyseal fractures. Can J Surg 1971;14: 127-35.

[19] Schatzker J, Waddell J, Stoll JE. The effects of motion on the healing of cancellous bone. Clin Orthop Relat Res 1989: 282-7.

[20] Claes L, Veeser A, Gockelmann M, Simon U, Ignatius A. A novel model to study metaphyseal bone healing under defined biomechanical conditions. Arch Orthop Trauma Surg 2009;129: 923-8.

[21] Thompson Z, Miclau T, Hu D, Helms JA. A model for intramembranous ossification during fracture healing. J Orthop Res 2002;20: 1091-8. 
[22] Claes LE, Heigele CA, Neidlinger-Wilke C, Kaspar D, Seidl W, Margevicius KJ, Augat P. Effects of mechanical factors on the fracture healing process. Clin Orthop Relat Res 1998: S132-47.

[23] Grongroft I, Heil P, Matthys R, Lezuo P, Tami A, Perren S, Montavon P, Ito K. Fixation compliance in a mouse osteotomy model induces two different processes of bone healing but does not lead to delayed union. J Biomech 2009;42: 2089-96.

[24] Rontgen V, Blakytny R, Matthys R, Landauer M, Wehner T, Gockelmann M, Jermendy $P$, Amling $M$, Schinke T, Claes L, Ignatius A. Fracture healing in mice under controlled rigid and flexible conditions using an adjustable external fixator. J Orthop Res 2010;28: 1456-62.

[25] Lutz M, Steck R, Sitte I, Rieger M, Schuetz M, Klestil T. The metaphyseal bone defect in distal radius fractures and its implication on trabecular remodeling-a histomorphometric study (case series). J Orthop Surg Res 2015;10: 61.

[26] Vicenti G, Pesce V, Tartaglia N, Abate A, Mori CM, Moretti B. Micromotion in the fracture healing of closed distal metaphyseal tibial fractures: A multicentre prospective study. Injury 2014;45 Suppl 6: S27-35.

[27] Gulliver G. On the Reparation of Fractured Bones; 1835.

[28] Cooper S. A Dictionary of Practical Surgery: Harper \& Bros.; 1845.

[29] Dupuytren, Clark FLG. On the injuries and diseases of bones. London,: The Sydenham society; 1847.

[30] Monfoulet L, Rabier B, Chassande O, Fricain JC. Drilled hole defects in mouse femur as models of intramembranous cortical and cancellous bone regeneration. Calcif Tissue Int 2010;86: 72-81.

[31] Kumagai K, Vasanji A, Drazba JA, Butler RS, Muschler GF. Circulating cells with osteogenic potential are physiologically mobilized into the fracture healing site in the parabiotic mice model. J Orthop Res 2008;26: 165-75.

[32] Schindeler A, Liu R, Little DG. The contribution of different cell lineages to bone repair: exploring a role for muscle stem cells. Differentiation 2009;77: 12-8.

[33] Siclari VA, Zhu J, Akiyama K, Liu F, Zhang X, Chandra A, Nah HD, Shi S, Qin L. Mesenchymal progenitors residing close to the bone surface are functionally distinct from those in the central bone marrow. Bone 2013;53: 575-86.

[34] Jungbluth P, Hakimi AR, Grassmann JP, Schneppendahl J, Betsch M, Kropil P, Thelen S, Sager $M$, Herten $M$, Wild $M$, Windolf J, Hakimi $M$. The early phase influence of bone marrow concentrate on metaphyseal bone healing. Injury 2013;44: 1285-94.

[35] Einhorn TA, Simon G, Devlin VJ, Warman J, Sidhu SP, Vigorita VJ. The osteogenic response to distant skeletal injury. J Bone Joint Surg Am 1990;72: 1374-8.

[36] Gazit D, Karmish M, Holzman L, Bab I. Regenerating marrow induces systemic increase in osteo- and chondrogenesis. Endocrinology 1990;126: 2607-13.

[37] Kaspar D, Neidlinger-Wilke C, Holbein O, Claes L, Ignatius A. Mitogens are increased in the systemic circulation during bone callus healing. J Orthop Res 2003;21: 320-5.

[38] Xiao W, Mindrinos MN, Seok J, Cuschieri J, Cuenca AG, Gao H, Hayden DL, Hennessy L, Moore EE, Minei JP, Bankey PE, Johnson JL, Sperry J, Nathens AB, Billiar TR, West MA, Brownstein BH, Mason PH, Baker HV, Finnerty CC, Jeschke MG, Lopez MC, Klein MB, Gamelli RL, Gibran NS, Arnoldo B, Xu W, Zhang Y, Calvano SE, McDonald-Smith GP, Schoenfeld DA, Storey JD, Cobb JP, Warren HS, Moldawer LL, Herndon DN, Lowry SF, Maier RV, Davis RW, Tompkins RG, Inflammation, Host Response to Injury Large-Scale Collaborative Research P. A genomic storm in critically injured humans. J Exp Med 2011;208: 2581-90.

[39] Gaudilliere B, Fragiadakis GK, Bruggner RV, Nicolau M, Finck R, Tingle M, Silva J, Ganio EA, Yeh CG, Maloney WJ, Huddleston JI, Goodman SB, Davis MM, Bendall SC, Fantl WJ, Angst MS, Nolan GP. Clinical recovery from surgery correlates with single-cell immune signatures. Sci Transl Med 2014;6: 255ra131.

[40] Sandberg $\mathrm{OH}$, Aspenberg P. Glucocorticoids inhibit shaft fracture healing but not metaphyseal bone regeneration under stable mechanical conditions. Bone Joint Res 2015;4: 170-5. 
[41] Sandberg O, Eliasson P, Andersson T, Agholme F, Aspenberg P. Etanercept does not impair healing in rat models of tendon or metaphyseal bone injury. Acta Orthop 2012;83: 305-10.

[42] Tu J, Henneicke H, Zhang Y, Stoner S, Cheng TL, Schindeler A, Chen D, Tuckermann J, Cooper MS, Seibel MJ, Zhou H. Disruption of glucocorticoid signaling in chondrocytes delays metaphyseal fracture healing but does not affect normal cartilage and bone development. Bone 2014;69: 12-22.

[43] Weber AJ, Li G, Kalak R, Street J, Buttgereit F, Dunstan CR, Seibel MJ, Zhou H. Osteoblasttargeted disruption of glucocorticoid signalling does not delay intramembranous bone healing. Steroids 2010;75: 282-6.

[44] Glass GE, Chan JK, Freidin A, Feldmann M, Horwood NJ, Nanchahal J. TNF-alpha promotes fracture repair by augmenting the recruitment and differentiation of muscle-derived stromal cells. Proc Natl Acad Sci U S A 2011;108: 1585-90.

[45] Zhang X, Schwarz EM, Young DA, Puzas JE, Rosier RN, O'Keefe RJ. Cyclooxygenase-2 regulates mesenchymal cell differentiation into the osteoblast lineage and is critically involved in bone repair. J Clin Invest 2002;109: 1405-15.

[46] Wu AC, Raggatt LJ, Alexander KA, Pettit AR. Unraveling macrophage contributions to bone repair. Bonekey Rep 2013;2: 373.

[47] Schlundt C, El Khassawna T, Serra A, Dienelt A, Wendler S, Schell H, van Rooijen N, Radbruch A, Lucius R, Hartmann S, Duda GN, Schmidt-Bleek K. Macrophages in bone fracture healing: Their essential role in endochondral ossification. Bone 2015.

[48] Raggatt $\mathrm{L}$, Wullschleger ME, Alexander KA, Wu AC, Millard SM, Kaur S, Maugham ML, Gregory LS, Steck R, Pettit AR. Fracture healing via periosteal callus formation requires macrophages for both initiation and progression of early endochondral ossification. Am J Pathol 2014;184: 3192-204.

[49] Alexander KA, Chang MK, Maylin ER, Kohler T, Muller R, Wu AC, Van Rooijen N, Sweet MJ, Hume DA, Raggatt LJ, Pettit AR. Osteal macrophages promote in vivo intramembranous bone healing in a mouse tibial injury model. J Bone Miner Res 2011;26: 1517-32.

[50] Guihard P, Boutet MA, Brounais-Le Royer B, Gamblin AL, Amiaud J, Renaud A, Berreur M, Redini F, Heymann D, Layrolle $P$, Blanchard F. Oncostatin $m$, an inflammatory cytokine produced by macrophages, supports intramembranous bone healing in a mouse model of tibia injury. Am J Pathol 2015;185: 765-75.

[51] Vi L, Baht GS, Whetstone H, Ng A, Wei Q, Poon R, Mylvaganam S, Grynpas M, Alman BA. Macrophages promote osteoblastic differentiation in-vivo: implications in fracture repair and bone homeostasis. J Bone Miner Res 2015;30: 1090-102.

[52] Godwin JW, Pinto AR, Rosenthal NA. Macrophages are required for adult salamander limb regeneration. Proc Natl Acad Sci U S A 2013;110: 9415-20.

[53] Obrant KJ. Trabecular bone changes in the greater trochanter after fracture of the femoral neck. Acta Orthop Scand 1984;55: 78-82.

[54] Draenert K, Draenert Y. The architecture of metaphyseal bone healing. Scan Electron Microsc 1979: 521-8.

[55] Bogoch E, Gschwend N, Rahn B, Moran E, Perren S. Healing of cancellous bone osteotomy in rabbits--Part II: Local reversal of arthritis-induced osteopenia after osteotomy. J Orthop Res 1993;11: 292-8.

[56] Bogoch E, Gschwend N, Rahn B, Moran E, Perren S. Healing of cancellous bone osteotomy in rabbits--Part I: Regulation of bone volume and the regional acceleratory phenomenon in normal bone. J Orthop Res 1993;11: 285-91.

[57] Kolios L, Hoerster AK, Sehmisch S, Malcherek MC, Rack T, Tezval M, Seidlova-Wuttke D, Wuttke W, Stuermer KM, Stuermer EK. Do estrogen and alendronate improve metaphyseal fracture healing when applied as osteoporosis prophylaxis? Calcif Tissue Int 2010;86: 23-32.

[58] Morgan EF, Mason ZD, Bishop G, Davis AD, Wigner NA, Gerstenfeld LC, Einhorn TA. Combined effects of recombinant human BMP-7 (rhBMP-7) and parathyroid hormone (134 ) in metaphyseal bone healing. Bone 2008;43: 1031-8. 
[59] Tsiridis E, Morgan EF, Bancroft JM, Song M, Kain M, Gerstenfeld L, Einhorn TA, Bouxsein ML, Tornetta P, 3rd. Effects of OP-1 and PTH in a new experimental model for the study of metaphyseal bone healing. J Orthop Res 2007;25: 1193-203.

[60] McDonald MM, Morse A, Mikulec K, Peacock L, Yu N, Baldock PA, Birke O, Liu M, Ke HZ, Little DG. Inhibition of sclerostin by systemic treatment with sclerostin antibody enhances healing of proximal tibial defects in ovariectomized rats. J Orthop Res 2012;30: 1541-8.

[61] Meunier A, Aspenberg P. Parecoxib impairs early metaphyseal bone healing in rats. Arch Orthop Trauma Surg 2006;126: 433-6.

[62] Aspenberg P, Genant HK, Johansson T, Nino AJ, See K, Krohn K, Garcia-Hernandez PA, Recknor CP, Einhorn TA, Dalsky GP, Mitlak BH, Fierlinger A, Lakshmanan MC. Teriparatide for acceleration of fracture repair in humans: a prospective, randomized, double-blind study of 102 postmenopausal women with distal radial fractures. J Bone Miner Res 2010;25: 40414.

[63] Skoglund B, Holmertz J, Aspenberg P. Systemic and local ibandronate enhance screw fixation. J Orthop Res 2004;22: 1108-13.

[64] Mills LA, Simpson AH. In vivo models of bone repair. J Bone Joint Surg Br 2012;94: 865-74.

[65] Aerssens J, Boonen S, Lowet G, Dequeker J. Interspecies differences in bone composition, density, and quality: potential implications for in vivo bone research. Endocrinology 1998;139: 663-70.

[66] Li X, Gu W, Masinde G, Hamilton-Ulland M, Rundle CH, Mohan S, Baylink DJ. Genetic variation in bone-regenerative capacity among inbred strains of mice. Bone 2001;29: 13440.

[67] Manigrasso MB, O'Connor JP. Comparison of fracture healing among different inbred mouse strains. Calcif Tissue Int 2008;82: 465-74.

[68] Petkova SB, Yuan R, Tsaih SW, Schott W, Roopenian DC, Paigen B. Genetic influence on immune phenotype revealed strain-specific variations in peripheral blood lineages. Physiol Genomics 2008;34: 304-14.

[69] Moran MM, Virdi AS, Sena K, Mazzone SR, McNulty MA, Sumner DR. Intramembranous bone regeneration differs among common inbred mouse strains following marrow ablation. $J$ Orthop Res 2015;33: 1374-81.

[70] Meakin LB, Sugiyama T, Galea GL, Browne WJ, Lanyon LE, Price JS. Male mice housed in groups engage in frequent fighting and show a lower response to additional bone loading than females or individually housed males that do not fight. Bone 2013;54: 113-7.

[71] Bernhardsson M, Sandberg O, Aspenberg P. Experimental models for cancellous bone healing in the rat. Acta Orthop 2015: 1-6.

[72] Procter P, Bennani P, Brown CJ, Arnoldi J, Pioletti DP, Larsson S. Variability of the pullout strength of cancellous bone screws with cement augmentation. Clin Biomech (Bristol, Avon) 2015;30: 500-6.

[73] McClelland D, Thomas PB, Bancroft G, Moorcraft Cl. Fracture healing assessment comparing stiffness measurements using radiographs. Clin Orthop Relat Res 2007;457: 214-9.

[74] Histing T, Klein M, Stieger A, Stenger D, Steck R, Matthys R, Holstein JH, Garcia P, Pohlemann $\mathrm{T}$, Menger MD. A new model to analyze metaphyseal bone healing in mice. J Surg Res 2012;178: 715-21.

[75] Stuermer EK, Sehmisch S, Rack T, Wenda E, Seidlova-Wuttke D, Tezval M, Wuttke W, Frosch $\mathrm{KH}$, Stuermer KM. Estrogen and raloxifene improve metaphyseal fracture healing in the early phase of osteoporosis. A new fracture-healing model at the tibia in rat. Langenbecks Arch Surg 2010;395: 163-72.

[76] Uusitalo H, Rantakokko J, Ahonen M, Jamsa T, Tuukkanen J, KaHari V, Vuorio E, Aro HT. A metaphyseal defect model of the femur for studies of murine bone healing. Bone 2001;28: 423-9.

[77] Alt V, Thormann U, Ray S, Zahner D, Durselen L, Lips K, El Khassawna T, Heiss C, Riedrich A, Schlewitz G, Ignatius A, Kampschulte $M$, von Dewitz $H$, Heinemann $S$, Schnettler $R$, 
Langheinrich A. A new metaphyseal bone defect model in osteoporotic rats to study biomaterials for the enhancement of bone healing in osteoporotic fractures. Acta Biomater 2013;9: 7035-42.

[78] Hausman MR, Schaffler MB, Majeska RJ. Prevention of fracture healing in rats by an inhibitor of angiogenesis. Bone 2001;29: 560-4.

[79] Street J, Bao M, deGuzman L, Bunting S, Peale FV, Jr., Ferrara N, Steinmetz H, Hoeffel J, Cleland JL, Daugherty A, van Bruggen N, Redmond HP, Carano RA, Filvaroff EH. Vascular endothelial growth factor stimulates bone repair by promoting angiogenesis and bone turnover. Proc Natl Acad Sci U S A 2002;99: 9656-61.

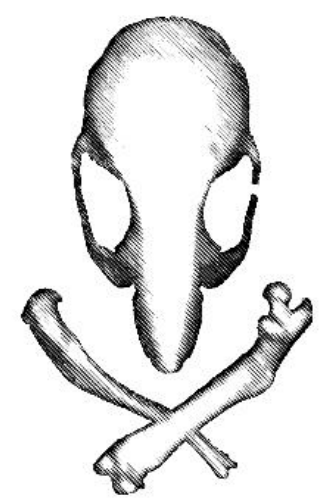




\section{Papers}

The articles associated with this thesis have been removed for copyright reasons. For more details about these see:

http://urn.kb.se/resolve?urn=urn:nbn:se:liu:diva-126148 